\title{
Optimization Strategy of Taxes and Parking Retribution Management
}

\author{
Rahmad*, Bambang Haryadi, Prasetyono \\ Master Program in Accounting, Faculty of Economics and Business, University of Trunojoyo Madura Jl. Raya \\ Telang PO. BOX 02, Kamal Bangkalan, Indonesia.
}

*Corresponding Author: Rahmad, Master Program in Accounting, Faculty of Economics and Business, University of Trunojoyo Madura Jl. Raya Telang PO. BOX 02, Kamal Bangkalan, Indonesia.

\begin{abstract}
The purpose of this study is to reveal and analyze the strategy for managing taxes and parking fees. The method used in this research is descriptive qualitative method with a case study approach, at Bapenda and Dishub with 13 informants. It includes methods of data collection (i.e. observation, interviews, and primary and secondary data collection), data analysis with SWOT analysis, and conclusions and suggestions. The results of this study indicate that the problems of parking taxes and levies is due to inadequate parking permits, inadequate location and potential surveys, conventional deposit collection, minimal parking taxes and charges, large number of illegal parking taxes and levies, inadequate guidance for parking owners, and unsustainable guidance for parking attendants. In addition, the optimization strategy for managing taxes and parking fees are socialization, rewards and sanctions (reward and punishment), increasing human resources, religiosity through spirituality in the workplace, integrity and self-commitment at work, commitment of not committing fraud, sustainable internal supervision and control.
\end{abstract}

Keywords: Problems, Strategy, Optimization, Management, Taxes and Parking Charges

\section{INTRODUCTION}

Regional autonomy gives flexibility to local governments in determining the allocation of resources into regional spending that adheres to the principle of appropriateness and necessity by taking into account regional capacities (Muin, 2014). According to Brodjonegoro et al (2005) regional autonomy policy is followed by fiscal decentralization (fiscal federalism) in which regions have the authority to regulate the portion of the development budget independently. Halim, (2012) stated that regional autonomy is the implementation of local governments in realizing local responsiveness, which means to accelerate regional social and economic development by providing access to the community as a form of community involvement in solving problems and facilitating anticipation of various problems that appear. In this case, one of the resources that need to be developed to increase PAD is local taxes and levies.

One of districts that contributes very little Regional Original Revenue (PAD) isBangkalan, so we need a way to reveal and analyze strategies in optimizing the management of taxes and parking fees to increase PAD. To optimize local revenue, one of the efforts made by Bangkalan is to increase income from various sources, both regional levies and taxes, one of which is from parking taxes and parking fees. So far, parking taxes and parking fees are still very small to contribute to the Regional Original Revenue in Bangkalan.

As Regional Apparatus Organization (OPD) that handles parking taxes and parking fees, the Regional Revenue Agency (Bapenda) and the Transportation Service (Dishub) have tried and maximized the strategy for optimizing parking tax and parking fees with all their efforts to contribute as much PAD as possible. Despite the fact that in the field there are still many obstacles, both from internal and external OPD. From the internal OPD itself there is still a lack of qualified resources in their fields, lack of optimal supervision, lack of socialization and also lack of strictness in implementing the rules that have been made. Meanwhile, from external OPD is the existence of community supports who still do not understand the importance of parking tickets, the large number of illegal parking, the dominance of third parties (blaters) who are not obedient to their obligations. Therefore it results in small tax revenues and parking fees in Bangkalan. By looking at the potential, as well as the strengths, 
weaknesses, opportunities and obstacles that exist in the implementation and management of parking in Bangkalan, it is actually still and very possible to be optimized again in achieving the target to contribute Regional Original Income (PAD).

Several previous studies conducted by Arvita (2010) stated that the main factor causing the low realization of parking fee receipts was the socialization factor. Rahmah (2016) stated that the planning process has been carried out very well by Dishubkominfo, as an organization responsible for parking management. The parking attendants in the field do a lot of irregularities, namely parking in prohibited areas, causing illegal parking, many parking attendants who do not collect fees according to rates, many parking attendants do not even deposit parking fees to the Transportation Agency and also lack of socialization by Transportation Agency. Reski (2013) stated that there is a lack of socialization and supervision on the part of the Transportation Agency, so that many people do not know the locations of subscription parking so that it becomes a field for jukir.

If the previous research examines more factors and constraints so that the target is not achieved without a strategy and analyzed with SWOT so that the achievement of the parking target is not achieved, then in this study the author will discuss strategies and assess or analyze with SWOT what is being done by Bapenda and Transportation Office of Bangkalan in facing problems and strategies in increasing Tax Revenue and Parking Charges in maximizing and optimizing existing potential by looking at the strengths, weaknesses, opportunities and threats that exist in Bangkalan.

So far, both Bapenda and Dishub Bangkalan have done socialization with the hope that the community understands and understands the importance of parking taxes and fees in contributing to local revenue, and can also improve services to the community while still paying attention to strengths, opportunities, threats and weaknesses in the management of these parking taxes and levies.

\section{LITERATURE REVIEW}

\subsection{Parking Tax}

Ismail (2008: 188) states that parking tax is a tax collected by local governments from parking management entrepreneurs or buildings, hotels, malls or other locations that manage parking. In Law Number 28 of 2009, tax has the meaning of compulsory contributions made by individuals or entities to the regions without a balanced direct compensation, which can be enforced based on the prevailing laws and regulations, which are used to finance the implementation of regional government and regional development. The implementation of regional autonomy by granting authority in the imposition of regional taxes is expected to further encourage local governments to be able to increase their PAD, especially from regional taxes and regional levies. Meanwhile, according to District Bangkalan Number 49 of 2012 concerning Parking Services, it states that parking tax is a tax on the operation of parking spaces outside of road bodies, both those provided in connection with the main business or provided as a business, including the provision of storage for motorized vehicles.

\subsection{Parking Retribution}

According to Bangkalan Regional Regulation No. 9/2010 concerning Public Service Charges, parking fees are payments for the use of parking space services determined by the Regional Government in accordance with the provisions of the applicable laws and regulations.

\subsection{Strategic Management}

According to (David, 2011: 6), strategic management is the art and knowledge of formulating, implementing, and evaluating cross-functional decisions that enable an organization to achieve its goals.

\subsection{Strategic Management Objectives}

According to Suwandiyanto (2010: 02), there are four strategic management objectives:

1. Giving direction to achieve organizational / company goals

2. Thinking about the interests of various parties

3. Anticipating any changes evenly

4. Relating to efficiency and effectiveness. 


\subsection{Process and Stages of Strategy Management}

David (2011: 6) explains that there are three stages in the strategic management process:
a. Strategy formulation
b. Strategy implementation
c. Strategy Evaluation

\subsection{Intensification}

According to Halim (2007: 113), intensification is an effort, action or efforts to increase acceptance, so that the desired target can be achieved or realized by conducting a more active, tighter and more thorough collection.

\subsection{Extensification}

Extensification is an effort to explore potential sources of new taxes or levies, which are expected to be able to contribute to increasing regional income.

\section{METHOD}

\subsection{Types of Research}

This research employed qualitative research. Qualitative research is a means to explore and understand the meaning of individuals or groups who are in contact with human, social, norms and ethical issues, and is used to explore and understand the symptoms or phenomena that occur by translating the complexity of a problem (Creswell, 2014).Furthermore, this type of research is a case study, with the hope of maintaining the characteristics or meaning of real life. A case study according to Yin (2011) is an empirical inquiry that investigates phenomena in the context of real life, where the boundaries between phenomena and contexts do not appear explicitly or clearly and use multiple sources or multiple sources of evidence. In this study, researchers chose case study research with descriptive analytical type.

\subsection{Research Location and Design}

The location of this research is the Transportation Office of Bangkalan and the Regional Revenue Agency (Bapenda) of Bangkalan, Bangkalan is chosen because the Transportation Service is a Regional Apparatus Organization (OPD) as the manager of Parking Charges and Bapenda is the Regional Equipment Organization (OPD) as the manager of Parking Tax.

The research design used a qualitative method with a comparative case study type approach. A comparative study is conducted to compare theory (laws and regulations) with cases found in the research location.

\subsection{Method of Collecting Data}

The data collection method used in this study is primary data as the main data, namely by conducting observations and interviews which are considered quite effective, which is done to answer the problems that are the topic of writing. Statistical data or documents in qualitative research are only supportive, because the main data of qualitative research are words and actions. The following data collection methods are used by the author:

1. observations.

2. interviews.

3. Secondary data collection

\subsection{Informant}

The informants in this study are people who have a working period of more than 3 years and have a long experience and background in managing taxes and parking fees. The following informants are the sources of data in the study:

1. Structural officer in Bapenda Bangkalan, structural officer of tax and retribution division II

2. Structural officials at Bapenda Bangkalan, Information and Technology Development Section and review of legislation as well as analysis and reporting 
3. Structural Officer for Infrastructure as the superior of the section for Operation of facilities and infrastructure

4. Facility Operations Section as the person in charge directly in charge of tax and parking fees

5. Parking Taxpayers and Parking Retribution Payers

6. The parking attendant as the spearhead in the parking manager or collector.

7. Community / Parking users as parking users

8. Parking Supervisor as well as Parking deposit withdrawal

9. One of the Budget Team from Bappeda

\section{FindingS}

\subsection{Parking Tax of Bangkalan in Numbers}

The contribution of parking tax in Bangkalan, both in terms of nominal and percentage, is still very minimal, this is due to the lack of extensification and intensification of parking tax management by Bapenda, although basically Bapenda has also held a moniv, but the results are still not satisfactory. In 2014 only contributed Rp. $191,235,870.00$ or $0.14 \%$ of the original regional income. In 2015 only contributed Rp. $175,159,300.00$ or $0.10 \%$ of the original regional income, in fact there was a decrease in income. In 2016 only contributed Rp. $298,721,560.00$ or $0.15 \%$ of the original regional income. In 2017 only contributed Rp. 182,605,300.00 or $0.06 \%$ of Local Own Revenue, in 2017 parking tax revenue is in freefall, and of course this needs to be taken concrete steps by optimizing management. (can be seen in Table 1 below).

Table1. Parking tax contribution to local revenue 2014 - 2017

\begin{tabular}{|l|l|l|l|l|}
\hline NO & YEAR & PAD & PARKING TAX & \% \\
\hline 1. & 2014 & Rp.135.785.489.733,88 & Rp. 191.235.870,00 & 0,14 \\
\hline 2. & 2015 & Rp. 175.624.054.291,43 & Rp. 175.159.300,00 & 0,10 \\
\hline 3. & 2016 & Rp. 200.073.202.553,75 & Rp. 298.721.560,00 & 0,15 \\
\hline 4. & 2017 & Rp. 325.525.663.295,62 & Rp. 182.605.300,00 & 0,06 \\
\hline
\end{tabular}

Source: $B P K A D$ Regency $X$

\subsection{Parking Retribution of Bangkalan in Numbers}

Pakir retribution contribution in Bangkalan Regency from 2014 s.d. In 2017, which contributed to PAD was still very small, namely: In 2014, parking fees contributed Rp. $741,557,000.00$ or $0.55 \%$ of Regional Original Income. In 2015, the Regional Retribution contributed Rp. 749,031,000.00 or $0.43 \%$ of the original regional income. In 2016, the Regional Levies contributed Rp. 730,680,500.00 or $0.37 \%$ of the original regional income. In 2017, the Regional Levies contributed Rp. $768,781,000.00$ or $0.24 \%$ of the original regional income. Nominally there is an increase from year to year except in 2016 there is a decrease, but if seen from the percentage contributed to PAD is very small and there is a decrease from year to year (can be seen in Table 2 below).

Table2. Contribution of parking fees to local revenue 2014 - 2017

\begin{tabular}{|l|l|l|l|l|}
\hline NO & YEAR & PAD & PARKING RETRIBUTION & \% \\
\hline 1. & 2014 & Rp. $135.785 .489 .733,88$ & Rp. 741.557.000,00 & 0,55 \\
\hline 2. & 2015 & Rp. 175.624.054.291,43 & Rp.749.031.000,00 & 0,43 \\
\hline 3. & 2016 & Rp. 200.073.202.553,75 & Rp. 730.680.500,00 & 0,37 \\
\hline 4. & 2017 & Rp. 325.525.663.295,62 & Rp. 768.781.000,00 & 0,24 \\
\hline
\end{tabular}

Source: BPKAD Bangkalan

\subsection{Parking Tax Management in Bangkalan}

In the implementation of parking tax management is based on Regional Bangkalan Number 8 of 2010 concerning Regional Taxes as a guideline in its implementation. In accordance with the Regional Regulation of Bangkalan Number 8 of 2010 concerning Regional Taxes, Part Eight Parking Tax, Article 48, Parking Tax is set at 30\% (thirty percent). From several results of interviews with researchers at Bapenda and observations of researchers in the field, it can be concluded that so far parking tax payments from taxpayers are still small / not up to 30\% as mandated by Perda Bangkalan and Bapenda still collect conventional parking taxes and this can affect ineffective implementation. Meanwhile, the results of the parking tax in the field are very large. 


\subsection{Management of Parking Fees in Bangkalan}

Management of Parking Charges in Bangkalan is based on the Regional Regulation of Bangkalan Number 9 of 2010 concerning Public Service Charges and the Regional Regulation of Bangkalan Number 10 of 2010 concerning Business Service Charges as guidelines for its implementation. In accordance with the Regional Regulation of Bangkalan Number 9 of 2010 concerning Public Service Retribution, the amount of parking fees on the side of public roads:

Structure1. Structure and Amount of Service Retribution Rates Parking on the side of a public road

\begin{tabular}{|l|l|l|l|}
\hline NO & TYPES OF FEE & RATES (Rp) & DESCRIPTION \\
\hline 1 & bike & 500,00 & / one parking \\
\hline 2 & Motorbikes & $1.000,00$ & /one parking \\
\hline 3 & Cars, Jeeps, Pick Up or the like & $1.500,00$ & /one parking \\
\hline 4 & Buses, Trucks and other heavy equipment & $3.000,00$ & /one parking \\
\hline 5 & Articulated trucks, attached car & $4.000,00$ & /one parking \\
\hline
\end{tabular}

Meanwhile, according to the Regional Regulation of Regency X Number 10 of 2010 concerning Business Service Levies, the amount of the levy for special parking spaces is like Structure 2 below:

Structure2. Structure and Amount of Service Retribution Rates Parking on the side of a public road

\begin{tabular}{|l|l|l|l|}
\hline NO & TYPES OF FEE & RATES (Rp) & DESCRIPTION \\
\hline A. & Parking fees in a special parking area & & \\
\hline 1 & Bike & 500,00 & Per 6 hours \\
\hline 2 & Motorcycle & $1.000,00$ & Per 6 hours \\
\hline 3 & Car, Jeep, Pick Up or the like & $1.500,00$ & Per 6 hours \\
\hline 4 & Buses, Trucks and other heavy equipment vehicles & $3.000,00$ & Per 6 hours \\
\hline 5 & Articulated trucks, patch cars per 6 hours \\
\hline B. & $\begin{array}{l}\text { A progressive parking levy in a special parking area is } \\
\text { imposed on motorized vehicles with a rate for the first 3 } \\
\text { hours equal to the rate as referred to in letter A and then } \\
\text { every 2 hours an increase of 20\% (twenty percent) }\end{array}$ & & \\
\hline
\end{tabular}

From some of the results of interviews at the Department of Transportation and the jukirnya it can be concluded that the parking rates charged or enforced in the field are not in accordance with the applicable regulations, namely the District Bangkalan. The researcher also made observations without the knowledge of Jukir and Parking Users and indeed the above is true, because this is also experienced by researchers as parking users.

\subsection{Problems and Efforts to Manage Taxes and Parking Fees in Bangkalan}

\section{A. Problems in managing taxes and parking fees}

In the management of taxes and parking fees, the authors divide into 3 (three) stages, namely: Planning, implementation, monitoring and evaluation. Where at each stage there are several problems / problems that require handling / strategies so that the management of parking taxes and fees can be optimal.

1. Planning taxes and parking fees

a. Parking permits are not optimal

b. The location survey and the potential for parking taxes and levies have not been maximal

2. Implementation of parking taxes and levies

a. Collection of tax deposits and parking fees is still conventional

b. Small parking tax deposit

c. The number of illegal parking taxes and levies

3. Supervision and evaluation of parking taxes and fees

a. Guidance on taxpayers and parking retribution payers is not maximal

b. Coaching to parking attendants is not continuous

B. Efforts made by Bapenda and Dishub Bangkalan

\section{Efforts to intensify parking taxes and levies}

Many research results conclude that increasing the contribution of local taxes and levies to PAD can be done with intensification or extensification efforts. Like the results of research conducted by 
Oktifauziah (2014) which concluded that an increase in the contribution of local taxes and levies to $\mathrm{PAD}$, it can be pursued through intensification and extensification.

This is no exception for Bangkalan itself, for the sake of realizing its regional independence, Bangkalan relies more on the source of Local Own Revenue which comes from local taxes and levies, one of which is taxes and parking fees and to date it continues to be optimized with the hope that later from These revenue sources can provide input to the regional treasury consistently. It is no less important that Bapenda and the Transportation Agency need to do is to build public awareness in general.

One of the things done by the Bapenda and the Transportation Agency in facing the challenge of increasing PAD is by providing socialization to the public regarding parking taxes and parking fees, especially those related to Regional Regulation Number 8 of 2010 concerning Regional Tax and Perda Number 9 of 2010 and Number 10 Year 2010 concerning Regional Levies. It is hoped that the socialization given to the community, parking lot and compulsory parking will have a better impact and will be successful in increasing local revenue, if the community also realizes and understands the importance of parking taxes and fees. The socialization efforts provided by Bapenda and Dishub have been intended with the aim of fulfilling the PAD revenue target, as well as an effort to increase understanding of the source of regional revenue and how to optimize both revenue and management.

The persuasive approach and door-to-door steps for the parking taxpayers and the mandatory parking fees are maintained even though they seem conventional, but this is still done by Bapenda and the Department of Transportation as a form of intensification of the regional revenue component in the regional business profit post. . Based on the description regarding these internal environmental factors, it can be summarized a number of things that are continuously being developed by Bapenda and Dishub in an effort to increase income in Bangkalan by paying attention to:

\section{Strength (Strength)}

- The existence of dynamic Regional Regulations

- Clear systems and procedures

2. Weaknesses

- Awareness of the public who do not understand the Regional Regulations

- Mastery and utilization of technology is not optimal

- Inadequate personnel competence

From several interviews and observations of researchers in the field, it can be concluded that so far Bapenda and Dishub Bangkalan have made socialization efforts to the community regarding parking taxes and fees by looking at the strengths and weaknesses that exist in the internal environment of the Regional Government. The socialization that is carried out directly (door to door) to the public regarding Regional Regulations Number 8 of 2010 and Regional Regulations Number 9 and 10 of 2010 as an effort to understand and fulfill the target of realization of parking taxes and fees

\section{Tax extensification and parking reduction efforts}

Until now, from the information obtained during the field of the Regional Government of Bangkalan, they still do not know exactly how much potential the region has, and this still requires further study. The district government plans to collaborate with a state higher education institution in the region, Bapenda and Dishub Bangkalan plan to make a book related to the potential of Bangkalan.

The results of interviews and observations of researchers in the field can be concluded, As a first step in extensification efforts, currently Bapenda and Transportation Agency are collecting data on taxpayers and mandatory parking fees, tax objects and a review of Regional Regulations related to regional taxes and levies which will then be carried out. adjustments to tariffs according to the current situation and conditions. In assessing and realizing this, it would take a long time and a lot of money. Optimization of the potential of Bangkalan for now will be more focused on natural resources and the resources of the apparatus themselves in relation to their readiness to face technological advances. In extensification efforts not only look at the potential of the regions, but also need cooperation from all parties. There is still a lack of cooperation from the community, compulsory parking and Jukir in 
Bangkalan, to jointly meet the target of PAD realization. Until now, the potential for regional income has not been explored in general due to a lack of sensitivity in finding cultural advantages and indigenous potentials, in addition to relatively lower tax / retribution compliance, weak legal systems and regional revenue administration, weaknesses in the apparatus, and bureaucratic worries about failure in running the program, and an attitude of not optimistic about the results that might be achieved. Now it remains what the role of stakeholders in the region in managing and optimizing existing resources and exploring other potentials in the area.

By looking at the external conditions that exist within the regional government of Bangkalan, it can be summarized the opportunities and threats which will then determine the strategy in increasing the local revenue, namely:

\subsection{The Strategy of Optimizing the Management of Parking Taxes and fees in Bangkalan}

\section{A. Internal strengths and weaknesses}

\section{Strength (Strength) in order to increase PAD}

The strengths that exist in the internal environment of the organization can be seen from the resources (input), process and performance (output). From the results of interviews conducted at Bapenda and Dishub Bangkalan, information was obtained about what were the driving factors in efforts to increase parking taxes and fees, including:

\subsection{Regional Regulations and District Head Regulations Bangkalan}

With the existence of laws, government regulations as well as regional regulations and regent regulations, especially Bangkalan Regional Regulation Number 8 of 2010 concerning Regional Taxes, Bangkalan Regional Regulation Number 9 of 2010 concerning Public Service Retribution, District Bangkalan Number 10 of 2010 concerning Business Service Retribution and Bangkalan Regent Regulation Number 49 of 2012 concerning Parking Services, make legal force for Bapenda and Dishub in implementing tax collection and parking fees. Perda and Perbup that have been made by the Regional Government are not merely rules that need to be read and completed, they are made to serve as guidelines, guidelines and instructions in implementing activities. With the existence of Regional Regulations and Regulations related to dynamic parking taxes and fees, there will be more opportunities or opportunities for the Bapenda and Dishub of Bangkalan to collect parking taxes and fees in accordance with the existing regulations in Perda and Pebup Bangkalan.

Based on the results of the observations that have been made, researchers still see that in the process of implementing the Regional Regulation of Bangkalan Number 8 of 2010 concerning Regional Taxes, Regional Regulation of Bangkalan Number 9 of 2010 concerning Public Service Charges, Regional Regulation of Bangkalan Number 10 of 2010 concerning Charges Business Services and Bangkalan Regent Regulation Number 49 of 2012 regarding Parking Services are still not maximal, including the intensive provision of tax collection and retribution which are not utilized. Although in terms of regulations, Perda and Perbup are internal strengths possessed by Bapenda and Dishub of Bangkalan in implementing tax collection and parking fees as a source of local revenue, in practice Bapenda and Dishub are still not free to apply and implement these Perda and Perbup. So that this Perda and Perbup can be used as a strength by Bapenda and Dishub Bangkalan.

\subsection{Adequate parking potential}

With the increasing number of motorized vehicles and the growing business world, both shopping centers, culinary centers and tourism places, this can affect the potential for taxes and parking fees that can be managed optimally by the Bapenda and the Transportation Agency of Bangkalan Regency In accordance with the results of interviews and observations of researchers, there are still many parking places that have not been managed / registered and licensed by Bapenda and Dishub.

The existence of places / potentials that have not been managed by Bapenda and Dishub (illegal parking) greatly affects local revenue, it should have a large potential (adequate) will make the strength (strength) for Bapenda and Dishub in an effort to increase Regional Original Income. Revenue from parking taxes and fees is one of the mainstays in both the province and the Regency / City, including Bangkalan Regency. Thus, it is necessary to have optimal management of the intensification and extensification of existing potentials. 


\section{Weekness in order to increase PAD}

Weaknesses that exist in the internal environment of the organization can also be seen from the presence of resources (input), processes and performance (output). From the results of interviews conducted at Bapenda and Dishub Bangkalan Regency, information was obtained about what were the hindering factors in efforts to increase parking taxes and fees, including:

\subsection{Weak control function}

From the results of interviews and observations of researchers on Bapenda and Dishub Bangkalan District Weaknesses (Weekness), one of which is the weak control function, both legislative and executive, starting from determining PAD targets in APBD so that PAD targets are small, as well as in the framework of implementing parking itself. This weak legislative control function is due to lack of data and the existence of budget politics in the discussion of APBD in Bangkalan Regency.

Supervision by the executive, especially Bapenda and Dishub, is needed because this will affect the implementation of parking in the field, both regarding the collection of parking services and the regulation of the vehicle itself (traffic). With this lack of supervision in the field, there are very many illegal levies by jukir either without official parking or fees that are not in accordance with those already outlined or stipulated in Bangkalan Regency Regional Regulation Number 8 of 2010 concerning Regional Taxes, Bangkalan Regency Regional Regulation Number 9 of the Year 2010 concerning Public Service Levies, Bangkalan Regency Regulation Number 10 of 2010 concerning Business Service Charges. This is very detrimental to PAD because the contribution to PAD is very small, but if monitoring can be done well, both by the legislature and the executive, this will be resolved and the contribution to PAD will be even greater.

\subsection{Lack of human resources in parking management}

The availability of skilled and qualified human resources in the field of tax administration and parking fees is still far from sufficient. And it is not impossible if the quantity of human resources is still used as a benchmark for the success of a program in increasing local revenue. Although the number of human resources owned by Bapenda and Dishub, especially in the field of tax collection and parking fees, is inadequate, they must be equipped with an increase in the quality of their human resources to support the implementation of their work. Not only that, the provision of facilities and infrastructure for the smooth running of work will motivate employees to complete their duties.

\subsection{The use of technology is not optimal}

Mastery and use of technology by both the Bapenda and the Transportation Agency are also part of the weaknesses that are still faced in realizing the vision and mission of their organization. This problem is reflected in the mastery and utilization of technology that is still conventional and there are still many systems that run partially both in collecting parking deposits and in licensing or other aspects, so it is likely that the information submitted is inconsistent, different versions of data and data are not. up-to-date (Khairunnisa, 2011).

\section{B. External opportunities and threats}

\section{Opportunity in order to increase PAD}

Opportunities in order to implement strategies to optimize and increase PAD are needed and considered as well as possible, because this greatly influences the success of a district / city in managing parking taxes and fees.

\subsection{Laws, Government Regulations and Presidential Regulations}

Law Number 28 of 2009 concerning Regional Taxes and Regional Levies, Law Number 19 of 2000 concerning collection by compulsory letter and Government Regulation Number 69 of 2010 concerning the Procedures for Providing and Utilizing Incentives and Tax Collection are regulations related to regional taxes and local levies, which also regulate parking taxes and fees, have provided opportunities for districts / cities to carry out activities to collect taxes and parking fees without worrying that they will overlap with regulations on central taxes.

Government Regulation Number 69 of 2010 concerning Procedures for Providing and Utilizing Tax Incentives and Collections is a reward for tax collectors both Bapenda and Dishub, in Chapter II it has 
been stated that incentives for collecting taxes and levies will be given at 3\% for the province and 5\% for the district government /City. This is intended as an effort to provide rewards to collecting agencies so that they will be motivated to collect taxes and levies as much as possible, but unfortunately in Bangkalan Regency this is not done, so the collecting agencies seem less motivated to increase their PAD.

Presidential Regulation Number 87 of 2016 Concerning the Task Force to Clean Illegal Levies, this can be applied to parking attendants who make illegal fees (extortion), this is intended as an effort to provide a deterrent effect on illegal practices, both illegal fees and illegal parking.

\subsection{Business development opportunities}

Utilization to optimize the management of parking taxes and fees in order to increase local revenue in Bangkalan can actually be increased again to support development sectors in this district. One example is business development in the area along the $\mathrm{X}$ road access which has the potential to be developed into an industrial area. However, so far there are still many business actors who are still hesitant to develop their businesses in this area. The majority of them argued that investing in this district must be faced with expensive and complicated licensing procedures, illegal levies from blaters and places to invest that are not yet well located.

\section{Threats in the context of increasing PAD}

Threats / challenges (treats) in order to carry out strategies to optimize and increase PAD are needed and considered as well as possible, because this is very influential on the success of a district / city in managing parking taxes and fees.

\subsection{The application of less firm legal sanctions (Law Enforcement)}

Until now, Bapenda and Dishub still do not have an effective enough way to implement legal sanctions for taxpayers who are negligent. However, the rules must still be applied, affirming sanctions that are reprimand, written and even actions for taxpayers and officers who commit violations must actually be implemented properly. Basically Bapenda and Dishub can cooperate with security forces to carry out control in matters of illegal fees and illegal parking so that it can create a deterrent effect on parking attendants and parking managers. It is unfortunate that until now this has never been done, so parking problems / problems will never be resolved properly as long as there is no good cooperation between all elements in Bangkalan, this will affect the size or size of PAD in Bangkalan.

\subsection{Lack of understanding and understanding of parking taxes and fees}

The problem of managing taxes and parking fees in Bangkalan is still not optimal because the managers and Jukir don't understand their rights and obligations, the majority in addition to relying on their egos, they don't want to know about their rights and obligations, so there are very many illegal and illegal parking fees. . The majority of almost all districts / cities in Indonesia face the same problem which is still not willing to pay taxes and parking fees in an orderly manner.

This problem is also faced by Bapenda and Dishub Bangkalan, until now there are still many parking managers who are always visited by collectors so they want to register their parking space and pay taxes or parking fees. I don't know what is their problem, whether it is due to their ignorance and lack of understanding of the laws or regulations governing parking taxes and fees or because of unfriendly services and procedures that are too complicated so they don't want to pay parking taxes and fees.

\subsection{The number of thugs (blaters) and community organizations in Bangkalan}

The number of thuggery (Blater) and community organizations in Bangkalan also influence the success in efforts to optimize the management of parking taxes and fees in Bangkalan. This can be in the form of objections regarding the obligations that must be carried out on existing parking taxes and fees In general, both blaters and community organizations, in general, depend on the results of this parking tax and retribution. These rejections by blaters and community organizations usually take the form of guarding and sometimes lead to criminal and anarchist acts.

A persuasive approach is the first step needed to provide understanding to the people in the field in the form of socialization about parking, so that the blaters and community organizations understand and understand the rights and obligations as taxpayers and parking fees, so that in the long run they can increase their coffers. PAD and not only go into private pockets. 


\section{STRATEgic STEPS In INCREASING PAD}

After analyzing the above data, the researcher took steps to map the strategic factors that exist in the organizational environment using the SWOT analysis tool (Strength, Weekness, Opportunity, Treat), which aims to determine the structure and strategic level of the existing factors. The stages or techniques of SWOT analysis are taken apart from being the initial stage in finding strategic issues, hope that further this analysis can later be used for strategic findings for the development of increasing regional income in Bangkalan. After seeing the strengths, weaknesses, opportunities and threats that exist in Bapenda or in Dishub Bangkalan in an effort to optimize local revenue through taxes and parking fees, it can be concluded with the following SWOT analysis technique matrix:

Table3. SWOT matrix for identifying strategic issues

\begin{tabular}{|c|c|c|}
\hline \multirow[t]{4}{*}{ Internal Environment } & STRENGTHS (S) & WEAKNESSES (W) \\
\hline & $\begin{array}{l}\text { 1.1 The existence of Regional Regulation and } \\
\text { Perbup }\end{array}$ & 2.1 Weak control function \\
\hline & 1.2 Adequate potential & 2.2 Lack of human resources \\
\hline & & $\begin{array}{l}2.3 \text { Technology Utilization has not } \\
\text { been optimal }\end{array}$ \\
\hline \multicolumn{3}{|l|}{ External Environment } \\
\hline $\begin{array}{l}\text { OPPORTUNITIES } \\
\text { (O) }\end{array}$ & SO Strategy & WO Strategy \\
\hline $\begin{array}{l}\text { a.1 Laws and } \\
\text { Government } \\
\text { Regulations }\end{array}$ & $\begin{array}{l}\text { 1. Law Number } 28 \text { concerning Regional } \\
\text { Taxes and Regional Levies, Law Number } 19 \\
\text { of } 2000 \text { concerning collection by compulsory } \\
\text { letter and Government Regulation Number } \\
69 \text { of } 2010 \text { concerning Procedures for the } \\
\text { Granting and Utilization of Incentives and } \\
\text { Tax Collection, Presidential Regulation } \\
\text { Number } 87 \text { of } 2016 \text { Regarding the Task } \\
\text { Force to Clean Up Illegal Levies }\end{array}$ & $\begin{array}{l}\text { 1. Carry out socialization related to } \\
\text { Law Number } 28 \text { Th. 2010, Law } \\
\text { Number } 19 \text { Year. 2000, and } \\
\text { Government Regulation Number } 69 \\
\text { Th. 2010, PerPres Number } 87 \text { Th. } \\
2016\end{array}$ \\
\hline $\begin{array}{l}\text { a.2 Business } \\
\text { Development } \\
\text { Opportunities }\end{array}$ & $\begin{array}{l}\text { 2. Carry out tax registration and data } \\
\text { collection, opening up opportunities for } \\
\text { cooperation with the private sector }\end{array}$ & $\begin{array}{l}\text { 2. Increasing human resources on } \\
\text { technology as an effort to support } \\
\text { increased local taxes }\end{array}$ \\
\hline THREATS $(T)$ & ST Strategy & WT Strategy \\
\hline $\begin{array}{ll}\text { b1. Less strict } \\
\text { application of legal } \\
\text { sanctions }\end{array}$ & $\begin{array}{l}\text { 1. Imposing sanctions for taxpayers who } \\
\text { violate parking taxes and fees }\end{array}$ & $\begin{array}{l}\text { 1. Increased understanding of the } \\
\text { importance of parking taxes and } \\
\text { fees }\end{array}$ \\
\hline $\begin{array}{lr}\text { b2. Lack } & \text { of } \\
\text { understanding } & \text { of } \\
\text { managers and } & \text { Jukir } \\
\text { about parking } & \text { taxes } \\
\text { and fees } & \\
\end{array}$ & $\begin{array}{l}\text { 2. Implement socialization of laws, } \\
\text { government regulations, presidential decrees, } \\
\text { regional regulations and regional regulations } \\
\text { on parking taxes and levies, sanctions on } \\
\text { extortion }\end{array}$ & $\begin{array}{l}\text { 2. Increased understanding of the } \\
\text { rights and obligations of managers } \\
\text { and jukir about parking taxes and } \\
\text { fees, penalties for extortion }\end{array}$ \\
\hline $\begin{array}{l}\text { b3. The number of } \\
\text { thuggery and } \\
\text { community } \\
\text { organizations }\end{array}$ & $\begin{array}{l}\text { 3. Conducting outreach on laws, PP, Perpres, } \\
\text { Perda and Perbup on parking taxes and fees, } \\
\text { illegal parking sanctions }\end{array}$ & $\begin{array}{l}\text { 3. Increased understanding of the } \\
\text { rights and obligations of managers } \\
\text { and jukir about parking taxes and } \\
\text { fees, sanctions for illegal parking }\end{array}$ \\
\hline
\end{tabular}

\subsection{PAD Increase Strategy}

In order to provide better services to the public in the future, the strategic planning tradition for the bureaucracy will be very useful, especially in spurring strategic thinking patterns regarding what the main mission of the organization is to be achieved, its long and short term goals, strategic plans, and plans. - operational plans, particularly programs and projects (Suryani, 2009).

This is reinforced by the opinion of Wheelen and Hunger (2012: 5), which defines strategic management as a solution to empower the entire organization to comprehensively and systematically realize the organization's vision and mission. To facilitate this, of course, support from within the organization is needed. The strategies needed by Bapenda and Dishub are: Socialization, Rewards and Sanctions (Reward and Punishment), Improvement of Human Resources.

\section{Socialization}

Dissemination strategies related to tax regulations and parking fees as an effort to intensify local taxes and fees. So far, the socialization provided by Bapenda and Dishub to the public, caretakers and 
parking managers is still passive, meaning that there are still many people, jukir and managers (the majority of blaters) who do not know for sure the rules and even the systems and procedures for registration and payment of taxes. And parking fees and their rights and obligations. This is because so far, the socialization carried out by Bapenda and Dishub is only limited to the Jukir neighborhood and the parking manager is not continuous, while for the community only through the announcement board only the amount of the parking fee.

The socialization provided to the community will have a better impact and will be successful in increasing local revenue, if the community also realizes and understands the importance of taxes and parking fees. The target of this socialization is not only for the parking lot and parking management, which is no less important towards the general public so that the public understands the benefits of parking taxes and levies themselves.

\section{Rewards and sanctions (Reward and Punishment)}

The strategy for implementing sanctions for OPD managers of parking taxes and fees (Bapenda and Dishub), Jukir and Parking Managers has so far been implementing sanctions and rewards that do not fulfill their obligations or have fulfilled their needs still cannot be applied firmly. An overhaul of the ewuh pakewuh attitude is carried out as soon as possible, because tax collectors may take firm action against taxpayers who do not want to carry out their obligations. In this case, the government has regulated it with Law Number 19 of 2000 concerning Collecting with a Warrant, In this law, especially in article 1 paragraph 9 , it is described that tax collection is a series of actions so that the tax bearer repays tax debt and tax collection fees by reprimanding or warns to carry out billing at once and at once, notifies a forced warrant, proposes prevention, carries out confiscation, carries out hostage-taking, sells goods that have been confiscated.

Government Regulation Number 69 of 2010 concerning Procedures for Granting and Utilizing Tax Incentives and Collections is a reward for tax collectors both Bapenda and Dishub, in Chapter II it has been stated that incentives for collecting taxes and levies will be given at 3\% for the province and 5\% for the district government /City. This is intended as an effort to provide rewards to the collecting agencies so that they will be motivated to collect taxes and levies as much as possible, but unfortunately in Bangkalan this is not done, so that the collecting agencies seem less motivated to increase their PAD.

\section{Increasing human resources}

Strategies for recruiting competent human resources in the field of taxation and parking fees. For now, the steps that have been taken by Bapenda and Dishub in recruiting employees are screening employees who really have the ability in the field of taxation and parking fees. Even if this is impossible, Bapenda and Dishub can provide opportunities for self-potential development to employees by participating in technical guidance related to taxation and parking fees, or training that is related to increasing PAD. In addition, it also provides opportunities for study assignments at a higher education level. Not only the fulfillment of the facilities and infrastructure that need to be fulfilled to support the increase in PAD, but also the support of employees who have the ability in the field of taxation and parking fees.

Increasing the quantity of collector officers, as well as improving the quality of employees on the understanding and ability of parking taxes and levies will indirectly affect the improvement of the services they provide. If the taxpayer feels comfortable with providing good service when paying taxes and parking fees, it is not impossible that it will have an effect on increasing regional revenues.

\section{Religiosity through spirituality at work}

Have and improve the mindset by always thinking positively (positive thinking) towards ourselves and others that are guided by religion and have good prejudice, so that if there are negative thoughts we will always think positively. A good understanding of religion, either directly or indirectly, can prevent individuals from actions that are prohibited by regulations (fraud), religion can be a filter that can prevent individuals from doing things that are against the rules because these actions will always be remembered and felt sin and try to keep away from sinning or breaking the rules.

Research results from Amaliyah (2015) prove that the religiosity hypothesis has a significant positive effect on fraud prevention through moderation of spirituality in the workplace. This means that a good understanding of religion and spirituality in the workplace will have a greater positive effect on fraud 
prevention. Individuals who have a good understanding of religion and spirituality but because the work environment is not conducive, this will lead to fraud. Therefore, spirituality in the work environment must be created from the leadership to the subordinates.

\section{Integrity and self-commitment at work}

Managers of parking tax and parking levies at Bapenda and Dishub must be committed and have integrity, because integrity is one of the most important attributes that a leader must have, people with integrity mean having an honest personality and having a strong character.Jack Welch (2005) in his book entitled "Winning" says, "integrity is a vague word (unclear). People with integrity speak the truth, and those people take their word.They take responsibility for their past actions, admit their mistakes and correct them. They know the laws that apply in their country, their industry and their company both express and implied and obey them. They play to win correctly (cleanly), according to the rules.

\section{Commitment not to commit fraud (fraud)}

The government through a program to form extortionate saber teams starting from the central level to the regional level with the aim of conducting shock therapy in eradicating behaviors and acts of fraud, as well as to eradicate extortion to the regions and has high hopes that it can spearhead the improvement of the government system in the future.

Commitment not to commit fraud must start from the highest level starting from the legislative, executive, judiciary, both central and regional so as to prevent practices that lead to fraud or commit fraud.For the implementation of management of parking taxes and fees, it must be started from the Head of the Agency or Service first, as a concrete step, it must be committed not to extortion to all subordinates by demonstrating continuously about this commitment to not fraud, as well as doing rewards and punishments for what employees do. by not ruling out the participation of external parties.

\section{Supervision and internal control on an ongoing basis}

Supervision and internal control on an ongoing basis is very necessary and is a very important aspect in supporting the effectiveness of the implementation of the anti-fraud strategy in the internal Bapenda and Dishub Bangkalan Regency. Supervision and control is equipped with an adequate information system in accordance with the complexity of problems that arise in each existing organization.

Likewise, local governments should not close their eyes in this internal supervision and control. They should always carry out internal supervision and control through the APIP (Inspectorate) and carry out direct checks in the field. Supervision and internal control are not only carried out based on existing administration, but must accommodate and pay attention to input and complaints from taxpayers and parking retribution compulsory to make input, so that they can make improvements to the system as soon as possible if there is an act or behavior deviating from the ASN on duty in the field, which in the end the target of parking taxes and charges can be achieved.

\section{SUGGESTION}

Hopefully this research can provide a good contribution to the implementation of optimizing the management of parking taxes and fees in Bangkalan, as for the suggestions for Bangkalan:

\section{Regulatory Revision}

Regional Regulation Number 8 of 2010 concerning Regional Taxes, Regional Regulation Number 9 of 2010 concerning Public Service Retribution, Regional Regulation Number 10 of 2010 concerning Business Service Charges and Regent Regulation Number 49 regarding Parking Services, all of which have expired (up to date) because they have no longer in accordance with the existing situation and conditions. What needs revising are:

a. Parking Retribution and Charging Adjustments 
So far, the collection is not in accordance with the local regulation on the grounds that there is no change and finding change is very difficult.

b. Duties and authorities

In the Perda and Perbup above, the OPD who manages Parking Tax and Retribution is Dishubkominfo, whereas since 2017, Dishubkominfo have been independent and all taxes are managed by Bapenda. So it is automatically null and void by law, and until now neither the regional regulation nor the regional regulations have been revised.

\section{Establishment of SOP}

So far, the Bapenda and Dishub Bangkalan have not yet available SOP (standard operational procedures) regarding the implementation of parking taxes and fees, so what happens is only policies, regulations can differ from one another and this can lead to conflict, for that it is necessary to stipulate SOP patent.

\section{REFERENCES}

[1] Amaliyah, Ima, (2015), "Fraud Prevention: relevance to religiosity and spirituality in the workplace", 2nd Global Conferenceon Business and social science-2015, GCBSS-2015, 17-18 september 2015, Bali, Indonesia.

[2] Arvita Betti (2010), Analisis Faktor-Faktor Penyebab Rendahnya Realisasi Penerimaan Retribusi Parkir Kota Padang

[3] Brodjonegoro, B., \& Martinez, J. (2005). An analysis of Indonesia's transfer system: recent performance and future prospect. In E. Elgar, Reforming Intergovermental Fiscal Relation and the Rebuilding of Indonesia. Massachusetts, USA: Edwarrd Elgar Publishing Limited.

[4] Creswell, J. W. (2014). Research Design "Pendekatan Kulitatif, Kuantitatif dan Mixed" Cetakan ke IV. Yokyakarta: Pustaka Pelajar

[5] David, Fred R. (2011). Strategic Management Manajemen Strategi Konsep, Edisi 12. Jakarta: Salemba Empat.

[6] Halim (2007:113) Akuntansi Sektor Publik : Akuntansi Keuangan Daerah (Vol. I). Jakarta : Salemba Empat

[7] Halim, A. (2012). Akuntansi Sektor Publik : Akuntansi Keuangan Daerah (Vol. IV). Jakarta : Salemba Empat

[8] Jack Welch (2005) dalam bukunya yang berjudul "Winning"

[9] Muin, F. (2014). Otonomi Daerah Dalam Perspektif Pembanguna Urusan Pemerintahan Daerah dan Keuangan Daerah. Fiat Justisia Jurnal Ilmu Hukum, 69-79

[10] Peraturan Pemerintah RI Nomor 69 Tahun 2010 Tentang Tata Cara pPemberian dan Pemanfaatan Insentif Pemungutan Pajak dan retribusi Daerah.

[11] Peraturan Presiden Nomor 87 Tahun 2016 Tentang Satuan Tugas Sapu Bersih Pungutan Liar.

[12] Peraturan Daerah Kabupaten Bangkalan Nomor 9 Tahun 2010 Tentang Retribusi Jasa Umum.

[13] Peraturan Daerah Kabupaten Bangkalan Nomor 10 Tahun 2010 Tentang Retribusi Jasa Usaha.

[14] Peraturan Daerah Kabupaten Bangkalan Nomot 8 Tahun 2010 Tentang Pajak Daerah

[15] Peraturan Bupati Bangkalan Nomor 49 Tahun 2012 Tentang Pelayanan

[16] Perbup Nomor 64 Tahun 2016 Tentang Kedudukan, Susunan Organisasi, Tugas dan Fungsi, serta Tata Kerja Badan Pendapatan Daerah

[17] Rahmah, Saffa (2018). Evaluasi Terhadap Pengelolaan Parkir Tepi Jalan Umum Di Kawasan Simpang Lima Kota Semarang.

[18] Reski, Ardeana (2013). Analisis Optimalisasi Retribusi Parkir Di Tepi jalan Umum Di kabupaten Tulungagung.

[19] Suwandiyanto, M. (2010). Manajemen Strategi dan Kebijakan Perusahaan. Online.

[20] Undang - Undang Nomor 28 Tahun 2009 Tentang Pajak Daerah dan Retribusi Daerah.

[21] Undang-undang Nomor 19 Tahun 2000 Tentang Penagihan Dengan Surat Paksa

[22] Wheelen, Thomas L., Hunger, J. David. (2010). Strategic Management and Business Policy Achieving Sustainability. Twelfth Edition. Pearson.

[23] Yin, Robert K, (2011). Studi Kasus : Desain dan Metode.Jakarta: Rajawali Pers.

\section{AUTHOR'S BIOGRAPHY}

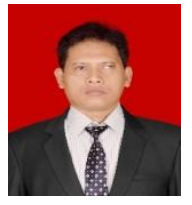

Rahmad, SE., M.Ak, is a Civil Servant (PNS) at the Communication and Information Office of Bangkalan Regency with a position as Head of the ICT Network Infrastructure Section. Lecture takes the Masters Program in Accounting, Faculty of Economics and 
Business, Trunojoyo University Madura Indonesia.

Citation: Rahmad, Bambang Haryadi, Prasetyono. “Optimization Strategy of Taxes and Parking Retribution Management" International Journal of Managerial Studies and Research (IJMSR), vol 8, no. 12, 2020, pp. 2538. doi: https://doi.org/10.20431/2349-0349.0812003.

Copyright: (C) 2020 Authors. This is an open-access article distributed under the terms of the Creative Commons Attribution License, which permits unrestricted use, distribution, and reproduction in any medium, provided the original author and source are credited. 